\title{
FORMATION OF SOCIO-ECONOMIC DEVELOPMENT STRATEGY OF CONSTRUCTION ENTERPRISES
}

\author{
Viktoriia Bozhanova \\ Department of Management, Project Management and Logistics \\ Prydniprovs'ka State Academy of Civil Engineering and Architecture \\ 24-a Chernyshevskoho str., Dnipro, Ukraine, 49000 \\ vyu7575@gmail.com \\ Oleksandra Kononova \\ Department of Accounting, Economics and Human Resources Management of Enterprise \\ Prydniprovs'ka State Academy of Civil Engineering and Architecture \\ 24-a Chernyshevskoho str., Dnipro, Ukraine, 49000 \\ oleksandrakononova@gmail.com
}

\begin{abstract}
The improvement of economic and social results of the current activity of a construction enterprise and future development of the socio-economic system is possible by forming and accepting complex arrangements within the mechanism of rationalization of cooperation between elements of the system of construction activity management, directed on establishing the organizational structure, providing balance between existent resources and establishing future aims for achieving economic and social results, observing the functional destination and objective orientation of technological and resource elements of the management system of the socio-economic development.

The conducted studies established that the strategy must provide arrangements as to improvement of the economic mechanism, system of management and planning, economic stimulation, creation of conditions for the effective use of the production potential of an economic enterprise. It was proved, that they are in: realization of profound marketing studies for determining a consumption demand for final construction products in whole and by their most important groups and usage directions; formation of alternative variants of creating final products, taking into account the structure of needs in them and within resources, allotted for the development of a construction enterprise; choice of a variant that mostly satisfies needs for a new strategy, solving socio-economic tasks at least costs, getting the proper quality of products and raising a competitiveness level of the production potential of a construction enterprise.

It allows to state that the development project of a construction enterprise must be based on multi-criteria optimization, oriented on getting the maximal profit and maximal satisfaction of the consumption demand of products, presented on internal and external markets at raising their competitiveness.
\end{abstract}

Keywords: strategy, strategic management, management, socio-economic development, competitiveness, construction enterprise.

\section{Introduction}

The notion of "strategy" is basic in the theory of strategic management, because it is just a uniting mechanism of aims, possibilities and conditions (external environment). Based on the business aims, it determines means, can be used by an enterprise for transforming its strategic intentions in market advantages, interacting with factors of an external influence, and its effective adaptation to strategic changes under conditions of uncertainty and changeability of the environment is impossible without it. The situation is also complicated by non-coordination of processes that take place within enterprises, economic activity management, inadequate to market requirements.

A strategy helps an enterprise to choose its rational development way and to create most important advantages in its functioning: prepares it to changes in the external environment; connects its resources with changes of the external environment; elucidates appearing problems; coordinates the work of different structural subdivisions; improves control at an enterprise. For providing the effective functioning of enterprises, a necessity of the scientific substantiation of strategies of their socio-economic development appears [1]. 
A special place in the development of a construction enterprise is occupied by a strategy of its socio-economic development. This strategy is a main constructive element of the long-term planning of processes at a construction enterprise. It determines main aims and tasks of the economic and social development of a construction enterprise, offers principal strategic solutions as to the development of all components of the production potential, substantiation of possible ways of increasing production volumes and solving social problems. Researches, directed on providing the complex approach to solving general economic, long-term scientific-technical and social tasks, and also priority of separate aims and programs of the socio-economic development of a construction enterprise, must be considered as topical ones. A development strategy as one of initial planning stages is a base of the further development of a plan in all its aspects by different functional subdivisions of the organizational management system of a construction enterprise, involving methodical means of planning and making decisions. Its substantiation in the working process on forming a plan of the socio-economic development strengthens the importance of purpose-oriented directionality at plans elaboration and also allows to separate immediately important problems that need preparing special problems and creating problem-purpose management groups that allows to determine ways of achieving set socio-economic aims in different spheres of the economic activity of a construction enterprise. It gives a qualitatively coordinated and quantitatively balanced working hypothesis of the development of a construction enterprise for future and the system of main indicators of this development.

Problems of a strategy and development of an enterprise are studied in works of both foreign and native scientists.

In work [2] it is noted, that the terms "strategy" and "strategic management" are relatively new and appeared in the second half of XX century. In that time there was a need in objective studying of processes, taking place at an enterprise, taking into account external tendencies and influence of factors.

In study [3] a strategy is a process of management for realizing the mission of an organization by managing this organization with its environment. Almost the same position is observed by authors of study $[4,5]$, who consider a strategy as a process of determination of a connection between an organization and its environment, including realization of chosen aims and trials for achieving the desirable condition of relations with the environment by distributing resources that allows an organization itself and its subdivisions to act effectively with good results.

According to [6], an economic strategy is a totality of mutually connected and mutually conditioned elements, united by the single global aim - to create and to support the high competitive advantage level of an enterprise. That is an economic strategy is a system of providing a competitive advantage. Work [7] determines an economic strategy as long-term, most principal, most important statements, plans, intentions of the government as to production, budget incomes and outcomes, taxes and capital investments, prices, social protection.

Study [8] notes that timely reaction on external challenges and rather often prophylactic arrangements provided survival of native enterprises in the context of globalization and production growth.

$[9,10]$ concentrate of the fact that native enterprises are characterized with a certain development and threats potential and also risks (branch, social, general and regional, financial, legislative) of an enterprise.

Analyzing study [11], let's note that a strategy of the socio-economic development of an enterprise is a long-term plan that includes the complex of solutions as to choosing the development direction of an enterprise, determination of its main aims and also a model of actions as to formation and effective use of its potential and gives a possibility to create favorable internal and external conditions for overcoming successfully main development stages in the system of economic safety.

Work [12] determines the process of choosing and forming a strategy of a construction enterprise for strengthening the competitive position at the market. In the most general case the process of choosing a strategy includes the following steps: analysis of a current situation and strategy; analysis of a potential order book; choice of a strategy of a construction enterprise and its estimation. A social component is included in this study quite narrowly, only as a factor of the internal and external environment. 
Studies $[13,14]$ determine and establish the composition of the complex mechanism of strategic management of a construction enterprise, present an algorithm of element by element formation of the composition and structure of the mechanism of strategic management of a construction enterprise and offer the internal structure of the complex mechanism of strategic management. But it must be noted, that this work doesn't give a social component of the mechanism of strategic management that testifies to the non-complex approach to the mechanism of strategic management of a construction enterprise.

Analyzing work [15] one can make a conclusion that a trial to combine approaches to formation of a strategy of a construction enterprise: system, situation and purpose-oriented in a single socio-economic system was made, but the use of only one of the aforesaid principles doesn't give a possibility to achieve necessary results - development of an enterprise in the long-term prospect.

Nevertheless, the problem of forming a strategy of the socio-economic development of construction enterprises needs additional studies.

So, the insufficient level of studying and unsatisfactory degree of elaboration of methods of strategic management of construction enterprises taking into account their current situation on the one hand, and their scientific and practical important - on the other one, determined the choice of the research theme and allowed to form the aim, tasks and circle of discussed questions.

\section{Aim of research}

To discover formation of a strategy of a construction enterprise by increasing the socio-economic development.

\section{Materials and methods of studying the process of forming a strategy of the socio-economic development of a construction enterprise}

For elucidating the set research aim, the standard methods of economic studies were used: logic - for elaborating main directions of realizing a strategy of the socio-economic development of construction enterprises; analysis, content-analysis and synthesis - for specifying main scientific categories of the research, substantiating new conceptual statements at solving research tasks; schematic and graphic image - for visible presentation of obtained research results; theoretical generalizations - for analyzing views of scientists-economists as to the research object and formulating conclusions of the conducted content-analysis of primary sources.

\section{Research results of elaboration of a strategy of a construction enterprise}

The following tasks were set for attaining the set aim:

- to substantiate requirements to intensification and increase of the production effectiveness, based on STP;

- to determine ways of improving the mechanism of market management with a social directionality as a main factor of the effective socio-economic development.

Just the aforesaid tasks also condition the succession of elaboration of strategies. The following important long-term problems are considered in it:

- economic condition of a construction enterprise and type of solving of social problems before the beginning of the plan period, objective conditions of reproduction next years;

- main aims and tasks of the effective socio-economic development of a construction enterprise, their priority that determines the succession of decisions and their mutual connection;

- involvement of new achievements of STP to solving of problems allows to realize an effective reconstruction of an enterprise, taking into account both closest and strategic prospects of the consumption development, and also to achieve the necessary level of the economic effectiveness of production;

- terms and main proportions of the development of a strategic enterprise, based on determining the necessary volume of labor and material resources in future and also on providing the detailed intensification of production;

- the development of scientific-research and projecting subdivisions of a construction enterprise for transferring on the innovative development way; 
- the development of production forces of a construction enterprise, mastering of new types of products for raising the stability of the innovative development way;

- the substantiation of a list of existent and new development programs and determination of initial realization parameters;

- production development volumes and improvement of processes of interaction of a construction enterprise with the external environment;

- the development of external economic connections and improvement of the structure of external trade;

- main directions of the social development, increase of material and culture levels of workers of a construction enterprise.

The promising development of the production potential of a construction enterprise, increase of welfare of its workers is determined in the close interconnection with problems of production relations, first of all, with the development of private property, increasing role of a main production link, strengthening principles of the socially-just distribution, creation of the integral system of the effective management of economy.

At the first stage of elaboration of a strategy of a construction enterprise there are analyzed: its economic condition; prospects of development; results of realization of an actual production plan, purpose-oriented complex programs of the development of production subdivisions of a construction enterprise, including resources, necessary for production.

The retrospective analysis of the qualitative condition of economy of a construction enterprise is combined with the wide use of different prognoses at elaborating a strategy: economic growth; STP; consumers' demand; changes of natural and economic conditions of the environment.

Prospective estimations of measuring general economic parameters of a construction enterprise must be based on the following prognoses of the construction branch: demographic, including a prognosis of changes of labor resources, reserves of natural resources and possibilities of their use; changes of production volumes of different building materials and instructions; STP; rates and proportions of the expanded reproduction (including prognoses of the development of main funds and investment policy); development of external economic connections and trade. Prognoses of the social development, growth of the consumption demand for construction products and services, changes of the environment and necessary arrangements on its saving are also important.

Prognoses must reflect not only formed tendencies, but also new economic realities, taking into account changes of the market infrastructure, social conditions and directions of STP. At the same time they must be rather real, so the previous coordination of growth tendencies of social needs and resources, based on balanced calculations, is needed.

A necessary condition of prognosticating studies, used at elaborating a strategy of a construction enterprise, is observance of the principle of mutual connection and balance of aims and resources. Coordination of different types of prognoses and their socio-economic results is reflected in the complex program of STP.

The following (second) stage at elaborating a strategy is substantiation of aims and tasks of the prospective period. Aims and long-term prospects of a construction enterprise are concretized in a strategy as a wide circle of tasks in the field of social, economic and innovation policy.

Aims of a plan and strategy form both as qualitative characteristics of directions of the socio-economic development and as volumes and levels that must be achieved by a construction enterprise in the production development and consumption demand satisfaction. At that the subordination of aims and tasks, priority and succession of their achievement are determined.

The content of a strategy includes not all, but only main aims that have a crucial importance and correspond to most important development problems. The presence of distinctly formed general aims and also tasks of the development of a construction enterprise provides concentration of economic resources for solving most important problems, create conditions for their successive decision.

The most importance for determining the development prospects of a construction enterprise is inherent to the social program elaboration. This program at the stage of strategy development includes determination of main tasks, directed on satisfying social needs of workers of 
a construction enterprise, ways of solving these tasks, taking into account a possibility to supply them with resources. Main statements of this section of a strategy are based according to a social policy, realized by a state. At the same time a development strategy must provide mechanisms of increasing the reverse influence of social factors on the production development, increasing its effectiveness by the better use of a human factor, more distinct stimulating influence of salaries and distribution of consumption funds.

The third important stage of a strategy is a program of increasing the technical level of production that includes a question of prospective planning, financing and stimulation of using last STP achievements and directions of the technical re-equipment of a construction enterprise.

This period usually takes several years, so it allows to use STP achievements more completely as a lever of the production volume growth and more complete satisfaction of social needs that is needs a systematic development of socio-economic arrangements for a long perspective.

A project of a strategy determines main aims and tasks of introducing last and prospective STP achievements. The most important element of this planning stage is determination of main characteristics and requirements to the construction equipment, planned to be introduced, and first of all, productivity and technical condition of machines and mechanisms, quality and exploitation properties of construction materials, efficiency of technologies, based on a necessity to achieve long-term tasks of the social and economic development of a construction enterprise.

The following stages may be separated as a strategy of the socio-economic development of construction enterprises under modern conditions (Fig. 1).

\begin{tabular}{|l|}
\hline $\begin{array}{l}\text { Formation stages of a strategy of } \\
\text { the socioeconomic development of } \\
\text { construction enternrises }\end{array}$ \\
$\begin{array}{l}\text { Stage 1. Analysis of a strategy of a construction enterprise. At this } \\
\text { stage there is realized the analysis of: its economic condition; prospects } \\
\text { of the development; results of realization of an actual production plan, } \\
\text { purpose-oriented complex development programs of production } \\
\text { sections of a construction enterprise, including resources, necessary for } \\
\text { production. }\end{array}$ \\
$\begin{array}{l}\text { Stage 2. Substantiation of aims and tasks of the prospective period. } \\
\text { Long-term aims of a construction enterprise are concretized in a } \\
\text { strategy as a wide circle of tasks in the branch of social, economic and } \\
\text { innovation policy. }\end{array}$ \\
$\begin{array}{l}\text { Stage 3. Elaboration of a program of increasing the production } \\
\text { technical level. This program includes questions of prospective } \\
\text { planning, financing and stimulation of using last STP achievements } \\
\text { and main directions of the technical re-equipment of a construction } \\
\text { enterprise. }\end{array}$ \\
\hline
\end{tabular}

Fig. 1. Main stages of formation of a strategy of the socio-economic development of construction enterprises

The following main problems are considered at the background of these requirements:

- the correct renovation of the structure of the active part of main funds, constructing materials, taking into account increasing their technical level and exploitation properties at the level of best perspective samples;

- the realization of wide complex mechanization of construction-assembling works, based on using means of light mechanization and new construction machines and mechanisms;

- the wide introduction of new construction materials, material fund of saving technological processes in production, decrease of costs and use of secondary resources;

- the maximal use of scientific and technical achievements, determination of main directions of the development of the scientific potential of a construction enterprise and ways of increasing the effectiveness of its use;

- the realization of large-scale arrangements for increasing the competitiveness of the production potential of a construction enterprise; 
- the realization of the effective innovation policy, directed on the most complete satisfaction of the consumption demand, taking into account purchasing possibilities of different population layers.

The complex strategic program of the innovative activity of a construction enterprise is a guarantee and means for realizing planned development aims in future. It includes:

- the formation of strategic directions of the scientific search for providing production with new project and constructive solutions taking into account development prospects of construction materials and technologies;

- arrangements as to introduction of last STP achievements in construction production and increase of their influence on the effectiveness and structure of the production process by improving labor instruments and subjects cardinally, using principally new technologies;

- the coordination of growth rates of the scientific and technical potential with volumes of necessary resources and creation of correspondent organizational conditions at the expanse of creating correspondent problem-purpose-oriented groups of the innovative development a construction enterprise.

The program of innovative development must pay the great attention to estimation of a readiness degree to conditions of using new construction and technological solutions. There must be also taken into account possibilities of using best world achievements, and it must be adapted to already existent problem-purpose-oriented programs.

The most important requirements of the effective technical development of a construction enterprise are to determine the comparative economic efficiency of different variants and choice of an optimal one.

But based on a chosen variant of the scientific-technical development and taking into account set socio-economic aims, a strategy determines quantitative characteristics of growth rates and main proportions of the economic development of a construction enterprise, volumes of production resources that it can use in future for solving its socio-economic program and development of the material-technical base.

Substantiation of rates and proportions at the stage of elaborating a strategy is realized on the base of the system of mutually connected variants of calculation by production growth factors using balanced micromodels that may include:

- the estimation of involvement of different resources in the economic circulation and also limitations as to their use in the production process;

- the calculation of the dynamics of labor resources, their distribution by construction objects and possible growth of the labor productivity (taking into account the planned mechanization of production, growth of electric, energetic and fund equipment and improvement of labor conditions;

- the estimation of the structure and volumes of main production funds;

- the determination of an influence of external economic conditions on the effectiveness of functioning of a construction enterprise.

An important problem of a strategy of the socio-economic development is to determine capital investments. Their volume is calculated using the growth of production volumes of a construction enterprise, resources of funds of accumulation and amortization and also calculations of the production balance by the dynamic model taking into account a final construction product that corresponds to aims of the economic and social development. At the same time there are taken into account all material resources, used in the production process.

Rates and proportions of the prospective development of a construction enterprise must be determined taking into account the transfer of economy on the intensive development way. It provides a necessity of the fullest use of present resources and STP achievements for the essential increase of the production effectiveness.

The quantitative estimation of an increased degree of the production effectiveness and its intensification must be expressed by the advancing growth of indices of final results comparing costs of all types of resources. For satisfying planned needs of a construction enterprise in fuel, construction materials and other type of material resources, the importance of saving, orientation 
of the technical development on decreasing the metal capacity of production at decreasing volumes of used fuel-raw material resources grow.

A strategy of the socio-economic development of a construction enterprise at elaborating main directions of its realization there must be provided by great arrangements for creating organizational and economic conditions of the production effectiveness. A strategy must be flexible and must provide necessary reserves for redistributing resources at deviations of actual production volumes from the planned level of the consumption demand satisfaction.

An important problem at constructing a strategy is the observance of balance of introduced factors. Such balance provides detail elaboration and rational limitation of a number and volumes of solved problems, concentration of resources on most prepared objects, taking into account the severe observance of a priority principle and rational succession at achieving planned socio-economic aims.

For providing balance of a development strategy, the following balances are elaborated:

- capital investments and main incomes;

- volumes of production and profit;

- costs and results;

- joint material balances of most important types of construction products, and also ones of production capacities according to the balance nomenclature, accepted in a strategy;

- joint financial balances.

Main requirements at elaborating the aforesaid balances for long-term perspectives are in the use of progressive norms and standards, provision of coordination of separate types of balances.

A result of the system of balance calculations at the strategic stage is a series of variants of the development of a construction enterprise, expressed in rates and proportions of its development. These variants include maximal, minimal and intermediate development indices.

The minimal variant of indices of the long-term development is elaborated, based on estimation of the lowest limit of widening consumption resources, usually based on extrapolation of dynamic tendencies of resources supply at the market and the effectiveness of their use.

The maximal variant (best by the effectiveness level) is constructed, based on the purpose-oriented approach. Its indices are coordinated with resources at such effectiveness levels of their use that provide achievement accepted levels of purpose-oriented indices till the fixed term. Corrections of purpose-oriented and resource indices and also effectiveness ones give different intermediate variants.

At elaborating a project of the production development of a construction enterprise there must be taken into account: realization of set aims of the socio-economic development, use of STP achievements, priorities in their realization, satisfaction of the consumption demand, effective use of main funds, production capacities, material and labor resources.

\section{Discussion of results of studying elaboration of a strategy of the socio-economic develop- ment of a construction enterprise}

At elaborating a strategy of the socio-economic development of a construction enterprise it is necessary to include:

- the realization of profound marketing studies for determining the consumption demand for final construction products in whole and by their most important group and usage direction;

- the formation of alternative variants of manufacturing final products taking into account the structure of needs in them and within resources, allotted for the development of a construction enterprise;

- the choice of a variant that mostly satisfies requirements of a new strategy, decision of socio-economic tasks at least expenditures, getting the given quality of products and increasing the competitiveness level of the production potential of a construction enterprise.

It is conditioned by the fact that a project of the development of a construction enterprise must be based on the multi-criteria optimization, oriented on getting the maximal profit and maximal satisfaction of the consumption demand in a region at increasing the competitiveness of products, manufactured at internal and external market. The prospect need in products, 
manufactured by a construction enterprise, must be determined, taking into account production volumes of competitors and economic niche, occupied by an enterprise at the construction product market.

Based on the necessary increase of production volumes, improvement of products' structure and increase of the quality, a strategy of the socio-economic development of a construction enterprise must include determined volumes of the technical re-equipment and reconstruction of production. The necessity and profitability of planned capital investments must be grounded. Orientation on the technical re-equipment for changing the morally archaic equipment and construction technique must be determining, because it is connected with the competitiveness of a construction enterprise. A strategy of the socio-economic development of a construction enterprise must take into account costs of capital investments, necessary for its realization. At that it is necessary to provide the given level of using existent production capacities and main funds, essential shortening of construction terms at the given quality of products and mastering of capacities, introduced into operation.

\section{Conclusions}

1. The conducted studies established, that a development strategy of a construction enterprise must be oriented at introduction of large-scale scientific-technical achievements, wide use of progressive resource-saving production technologies, complex mechanization and automation, increase of changeability, development of specialization and cooperation of a construction enterprise. This base must provide the essential increase of the production effectiveness; labor productivity growth; decrease of material and energy capacity of products; decrease of a cost of a product unit, including a capacity unit of machines and construction technique.

2. The special attention must be paid to the profitability of planned arrangements of the technical re-equipment of a construction enterprise for estimating real volumes of the achieved labor economy and material costs, including at the expanse of thorough reduction of wastes and losses, replacement of deficit natural construction materials by their artificial types, maximal use of secondary resources. Alongside with the production efficiency increase at the expanse of technical re-equipment and improvement, a construction enterprise must also take into account the influence of staff qualification and education improvement, improvement of social conditions of their labor and life. problems:

A strategy of arrangement of productive forces solves the following most important

- tasks of involvement of new region districts, based on their construction materials usage;

- main problems of the social development of a region;

- the formation and development of complex programs of arrangement of production process;

- the most effective use of natural and labor resources, main funds.

The special attention must be paid to conclusion of long-term treaties with suppliers, taking into account a task of constructing the optimal transport supplying network.

Synchronously with developing a strategy, there is considered a condition of preparing problem-purpose-oriented complex scientific-technical, economic and social programs of the prospective development, creation of correspondent problem-purpose-oriented groups of realization management within the existent organizational management structure.

At that for new problem-purpose-oriented, there are determined:

- problems that need decision on the program base;

- a duration of a problem decision, including one at its separate stage;

- approximate expenditures for capital investments for solving a problem;

- needs in working forces and material resources.

A strategy must provide arrangements as to improving the economic mechanism for improving the management system, planning, economic stimulation, creating conditions for the effective use of the production potential of a construction enterprise. 


\section{References}

[1] Kravchenko, O. V. (2010). Ponyattya strategiyi rozvitku pidpriemstva. Visnik Sumskogo natsionalnogo agrarnogo universitetu, 1 (22), 267-272.

[2] Raizberg, B. A. (2014). The course of economics. Moscow: INFRA-M, 686.

[3] Matsuyama, K. (1992). Agricultural productivity, comparative advantage, and economic growth. Journal of Economic Theory, 58 (2), 317-334. doi: http://doi.org/10.1016/0022-0531(92)90057-o

[4] Meadows, D. H., Randers, J., Meadows, D. L. (2004). Limits to Growth: The 30-Year Update. Vermont: Chelsea Green Publishing, 338.

[5] Goryushkin, A. A., Novitskiy, N. I. (2010). Organization of production. Moscow: KNORUS, 350.

[6] Talavyria, O. M. (2016). Aspekty rozrobky ekonomichnoi stratehii rozvytku pidpryiemstv. Naukovyi visnyk Uzhhorodskoho universytetu. Seriia «Ekonomika», 2 (1 (47)), 335-339.

[7] Kozak, Yu. H., Kovalevskyi, V. V., Lihanenko, I. V. (2009). Mizhnarodni stratehii ekonomichnoho rozvytku. Kyiv: Tsentr uchbovoi literatury, 356.

[8] Kolesov, N. A., Uraev, N. N. (2012). Problems and limitations of the production systems of domestic enterprises. Bulletin of AN Tupolev KSTU, 4, 20-23.

[9] Uraev, N. N. (2014). Economic content of the development strategy for the radio-electronic industry. The Evolution of Russia's economic model: the experience of the past as the basis for the future, $345-350$.

[10] Uraev, N. N. (2014). Methodology of strategic development of manufacturing processes for a provident enterprise. Journal of economics, law and sociology, 2, 65-68.

[11] Zbarskyi, V. K. (2013). Sutnist poniattia «stratehiia rozvytku» maloho pidpryiemstva. Naukovyi visnyk Natsionalnoho universytetu bioresursiv i pryrodokorystuvannia Ukrainy. Seria «Ekonomika, ahrarnyi menedzhment, biznes», 181 (6), 36-45.

[12] Kononova, O. E. (2013). Protses viboru strategiyi budivelnogo pidpriemstva. Ekonomika. Upravlinnya. Innovatsiyi, 2 (10). Available at: http://nbuv.gov.ua/UJRN/eui_2013_2_40

[13] Kononova, O. E. (2015). Metodologiya formuvannya kompleksnogo mehanizmu strategichnogo upravlinnya buiivelnim pidpriemstvom. Globalni ta natsionalni problemi ekonomiki, 3, 328-331.

[14] Kononova, O. (2016). The study of methodology of formation of the complex mechanism of strategic management of building enterprise. EUREKA: Social and Humanities, 5, 18-26. doi: http://doi.org/ 10.21303/2504-5571.2016.00181

[15] Kononova, O. E. (2016). Stan i tendentsiyi rozvitku strategichnogo upravlinnya v Ukrayini. Visnik Odeskogo natsionalnogo universitetu. Seriya: Ekonomika, 21 (7-1 (49)), 99-104. 